
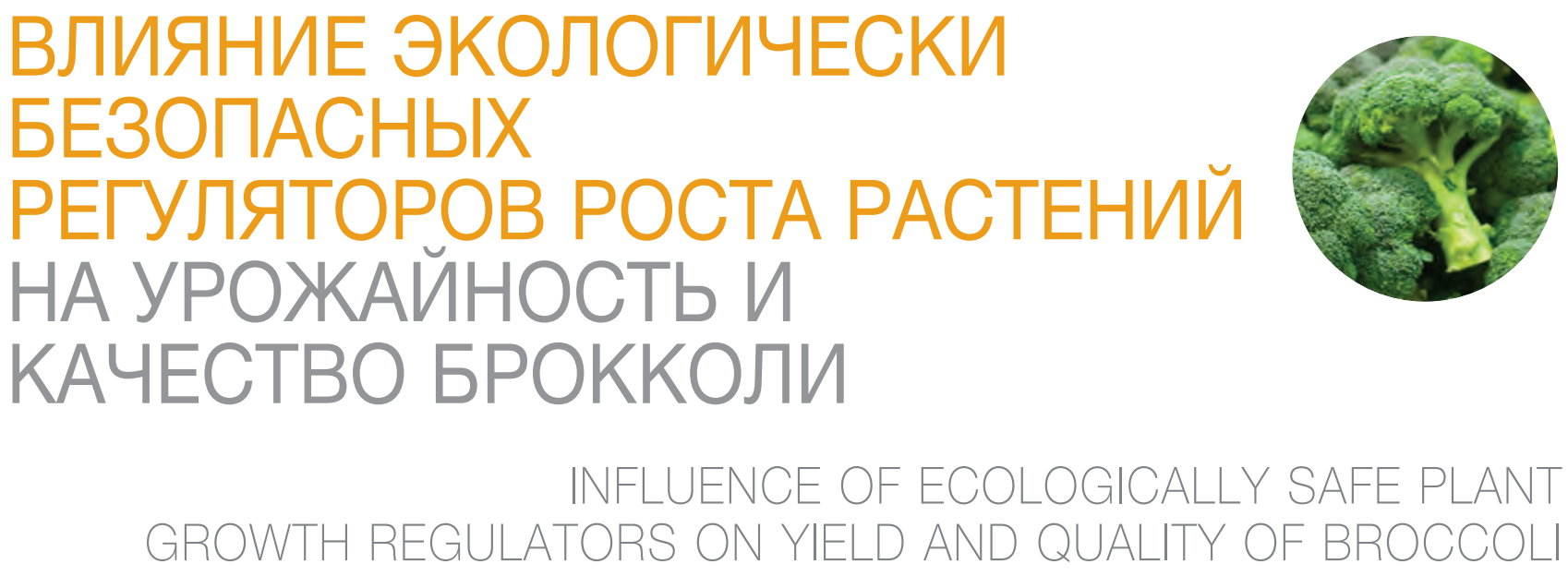

Гаджимустапаева Е.Г.- кандидат с.-х. наук, старший научный сотрудник

Дагестанская опытная станция ВИР Россия, Республика Дагестан, Дербентский район, с. Вавилово E-mail: vir-evg-gajimus@yandex.ru

Проведено изучение ростостимулирующих препаратов: Агростимул, Лигногумат, Экосил и Organobor (Br) на капусте брокколи. Установлено, что сортовая реакция по динамике нарастания ассимиляционного аппарата при обработке препаратами неодинаковая. Отмечена избирательная особенность сортов брокколи. Проведен анализ обработанных стимуляторами сортов брокколи по продуктивности, скороспелости, качеству продукции, дружности созревания головок, продолжительности периода вегетации и темпов роста растений в сравнении с контролем. В результате наблюдений установлено, что период наступления хозяйственной годности сортов брокколи значительно варьировал в зависимости от температурного режима года, и, в частности, от времени наступления оптимальной для образования головок температуры. Использование ростостимулирующих препаратов в открытом грунте южных регионов страны перспективно в целях повышения адаптивности и урожайности растений при круглогодичном выращивании овощей и неоднократном использовании единицы пахотной земли. Обработка рассады и вегетирующих растений после высадки и в начале образования головок ростостимулирующими препаратами является эффективным способом стимуляции роста и развития растений и ускорения формирования головок брокколи. В наших исследованиях большую эффективность проявил препарат Агростимул, повышая урожайность центральных головок у сорта Burpess green bud на 181\%, у Hybrid Cape Queen - на 134\%, а дополнительных (I-III порядка) - на 445 \% и 131\%, соответственHO.

Ключевые слова: брокколи, ростостимулирующие препараты, формирование головок, урожай I-III порядка, скороспелость.
Gadzhimustapaeva E.G.

Dagestan Experimental Breeding Station, VIR Vavilovo, Derbent region, Republic of Dagestan, Russia E-mail: vir-evg-gajimus@yandex.ru

The plant growth stimulating preparations such as Agrostimul, Lignogumat, Ecosil and Organobor $(\mathrm{Br})$ were tested in broccoli. It was shown that variety reaction in dynamic of growth of assimilation apparatus was different when treating with the preparations. The different plant responses were noticed among broccoli cultivars. The data analysis was carried out, where treated with stimulators cultivars were estimated for productivity, early-maturation, output quality, simultaneously-matured heads, duration of vegetation period, and rates of growing in comparison with control variant. As a result of the study, it was shown that economic suitability of broccoli cultivars varied depending on year temperature, and particularly the optimal time when broccoli formed heads. The application of growth stimulating preparations in open field of southern regions is very promising, in order to enhance the adaptability and yield capacity during yearround cultivation and multiple utilization of a soil unit. The treatment of seedlings and vegetative plants after having been planted and at the beginning of head formation with growth stimulating preparation was very effective way to stimulate the growth and development and to hasten broccoli head formation. In our study, the preparation Agrostimul was the most effective in increasing the yield of central heads by $181 \%$ in cultivar Burpess, Green Bud and hybrid, Cape Queen by $134 \%$, while the yield of extra heads from the first to the third was increased by $445 \%$ and $131 \%$, respectively.

Keywords: broccoli, growth-stimulating preparations, head formation, yield of first-third heads, early-ripening.
Dокколи (Brassica oleracea L. var.
cymosa Duch.=var.italica Plenck) свое название получила от итальянского слова covolo broccolis (стеблевая капуста). Культура более холодостойкая, чем капуста цветная. В последнее время брокколи получила распространение во многих странах мира $[1,2]$. Родиной всех воздельгдемых видов капусты считают
Средиземноморье, где в прибрежных районах Италии и сейчас можно встретить дикорастущие формы [1].

По содержанию элементов минерального питания брокколи занимает ведущее место не только среди других видов капусты, но и среди овощных культур. В соцветиях и стеблях содержится белка и витамина С в два-три раза, а витамина E - в пять раза больше, чем в капусте цветной. Брокколи богататакими веществами, как холин и метионин, препятствующими накоплению в организме холестерина и предохраняющими организм от преждевременного старения[3].

По данным диетологов (Лобыкина Е.Н. и др., 2007), продукты, содержащие угле- 
воды с низким гликемическим индексом (<40\%), - это, в основном, овощные, зеленные культуры, фрукты, ягоды. Так в 600 г брокколи содержится порция, равная одной хлебной единице [4].

Продуктовый орган брокколи головка, пучок плотных бутонов на нежном стебле, по форме схожа с капустой цветной. Окраска головки разнообразна: темно-зеленая, зеленая, фиолетовая, синеватая и белая $[1,5,6]$. Брокколи отличается пряным вкусом, напоминающим вкус сырого грецкого opexa.

Процесс ветвления охватывает все побеги как первого, так и последующих порядков, в результате чего размер головки интенсивно растет и увеличивается [7]. Ранние сорта формируют некрупную, рыхлую головку, а в пазухах листьев появляются боковые мелкие головки. Позднеспелые сорта брокколи сначала формируют крупную плотную центральную головку, а после ее срезки начинают развиваться боковые.

Лист лировидный, длинночерешковый. Стебель длинный 60-95 см,число листьев достигает 45 шт.

Брокколи холодостойка, выдерживает заморозки до $-6 \ldots-9^{\circ} \mathrm{C}$.

В настоящее время рынок выдвигает требования по улучшению обеспечения населения овощной продукцией, расширению ассортимента и поступлению ее в течение всего года. В связи с необходимостью получения стабильных урожаев, ежегодно возрастает интерес к различным физиологически активным веществам. Создаваемые в последние годы рострегулирующие препараты на основе природного сырья, обладающие одновременно несколькими видами активности, открывают новые подходы к управлению процессами метаболизма растений, и позволяют шире решать задачи практического растениеводства, при этом являются экологически безопасными [5, 6, 8, 9]. Матевосян Г.Л. и др. (2008) отмечают, что комплексная обработка семян, рассады и вегетирующих растений после высадки рассады и в начале образования головки фиторегуляторами является весьма эффективным способом стимуляции роста и развития растений, активации физиологического состояния растений, инициирования образования и ускорения формирования головок капусты цветной $[6,10]$.
Условия и методы исследования

На Дагестанской ОС ВИР в 2015/2016 годах были заложены мелкоделяночные опыты с целю определения влияния биологически активных веществ на рост растений, качество продукции и дружность созревания капусты брокколи. Объектом исследований являлись два сорта: Burpess green bud (США) и Hybrid Cape Queen (Япония). Выбор сортов был обусловлен предыдущими исследованиями 2013-2014 годов, в результате которых были выделены образцы с высокой продуктивностью и качеством головок, однако их вегетационный период и дружность созревания головок были растянуты. В связи с этим продолжили работу с данными сортами, исследуя влияние ростостимулирующих препаратов на растения брокколи.

Анализ метеорологических показателей сезона вегетации 2015 и 2016 годов свидетельствовал о неблагоприятных для растений брокколи погодных условиях.
Начиная с І-й декады июня 2015 года, стояла жаркая сухая погода:температура $26,2^{\circ} \mathrm{C}$ (рис. 1.) и влажность воздуха - 59\%. Максимальные значения среднесуточныхтемператур были выше среднемноголетних показателей на 8,8-9,1․ В июле наблюдали наибольшее термическое напряжение и повышенную солнечную активность. Жаркая погода практически сохранялась два с лишним месяца. Максимальная температура воздуха в летний период достигала $35,7^{\circ} \mathrm{C}$. Засуха особенно сильно ощущалась в 2-3 декадах июня. Спорадическое выпадение осадков было отмечено во 2-3 декадах июля. Большое количество осадков выпало в октябре - 140,6 мм и в ноябре - 160 мм, что выше климатической нормы в 3-4 раза (рис. 2.).

Лето 2016 года было также жарким, влажность воздуха составляла 64\%. Сумма осадков за три месяца июнь-август составила 113,1 мм. Максимальная температура воздуха в летние месяцы достигала $35,6^{\circ} \mathrm{C}$.

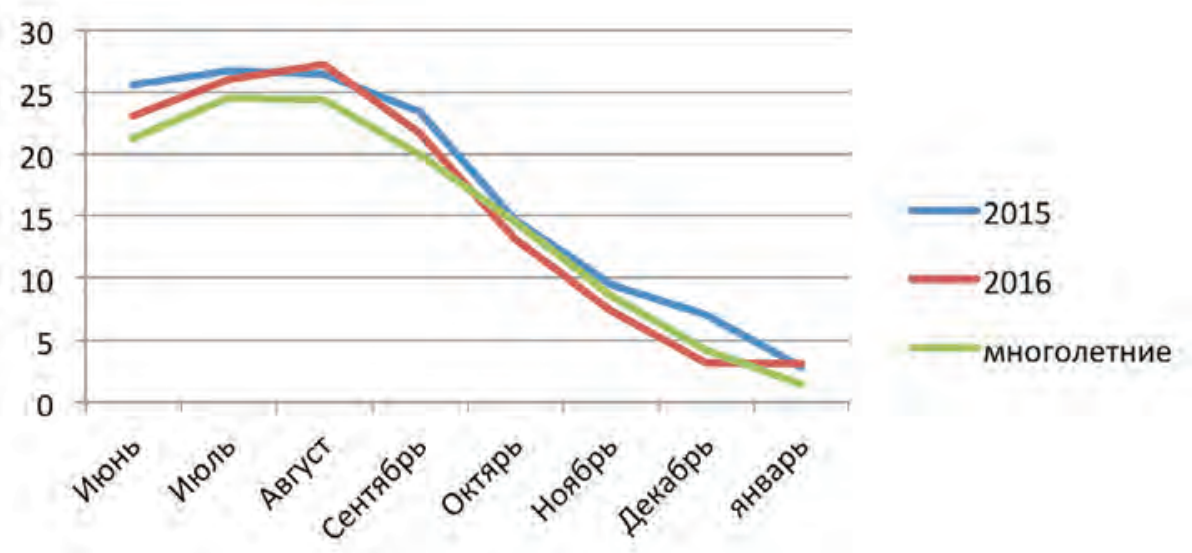

Рис. 1. Температура воздуха период вегетации капусты брокколи.

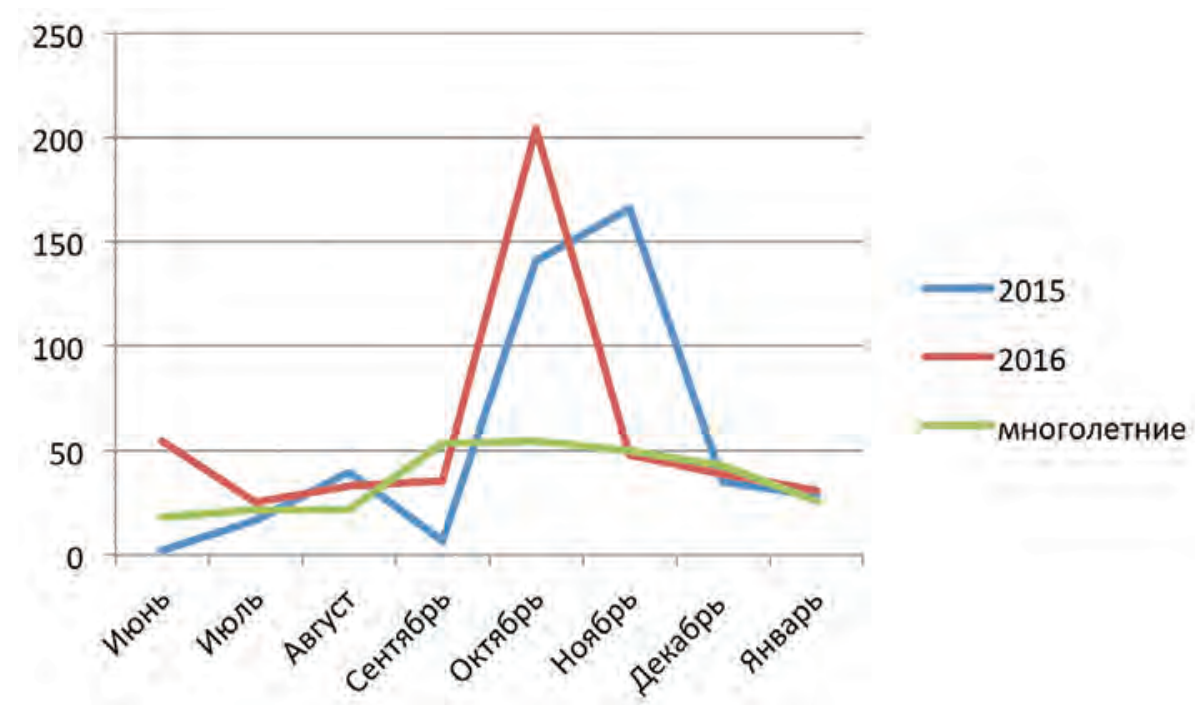

Рис. 2. Количество осадков в период роста и развития капусты брокколи. 
Осень была прохладная и дождливая, периодически выпадали незначительные осадки. Осадки выпали выше нормы в октябре - 204,0 мм. В ноябре выпал снег, минимальная температура воздуха достигла $-1,5^{\circ} \mathrm{C}$, в декабре $--6,4^{\circ} \mathrm{C}$. Погодные условия были неблагоприятны для вегетации растений.

Нами было заложено 4 варианта в трехкратной повторности с использованием рострегулирующих веществ: Агростимул, Лигногумат [11], Экосил, Organobor (Br), в качестве контроля обработка водой.

Рассаду брокколи обрабатывали в два срока: в фазу 2-3 листьев и 6-7 настоящих листьев перед высадкой. Размещение делянок - рендомизированное. Схема посадки рассады 0,7×0,4 м, площадь питания 0,28 м. Площадь каждой повторности - 8,4 м² по 30 растений. Посев семян производили 17 июня, высадку рассады 27-30 июля. Статистическую обработку экспериментальных данных проводили методом дисперсного анализа [12].

\section{Результаты исследований}

В современных условиях эффективное и рациональное использование земельных ресурсов связывают не только с увеличением выхода продукции с единицы площади, снижением затрат на производство единицы продукции, но и с сохране- нием или повышением плодородия почв, охраной окружающей среды [13], улучшением качества продукции [14] и возможностью круглогодичного обеспечения свежей продукцией населения региона [15].

Скороспелость капусты брокколи зависит от ее генотипа, условий выращивания, среди которых важную роль играет температурный фактор. Применение ростостимулирующих препаратов оказало значительное влияние на продолжительность фенофазу растений сорта Burpess green bud в начальный период завязывания головок (табл.1). Начало формирования головки (у 10\% растений) при обработке препаратом Агростимул отмечено на 9 суток раньше контрольного варианта. Формирование технической спелости головок (у 100\% растений) происходило дружно, и фаза сокращалась на 19 суток. Уборку урожая брокколи проводили в течение 23 суток. У растений, обработанных препаратами Лигногумат, Экосил, Organobor (Br), дату созревания головок 10\% растений наблюдали позже контрольного варианта на 4, 20 и 17 суток, соответственно, однако полное созревание (у 100\% растений) было более дружным, и уборку головок осуществляли в течение 15, 25, 23 суток (в контроле 44).

Сортообразец Hybrid Cape Queen при изучении в 2015-2016 годах показал себя как средне-позднеспелый. Начало формирования (у 10\%) головок при обработке ростостимулирующим препаратом Агрстимул отмечено на 13 суток позже, а препаратами Лигногумат и Экосил - на 26, a Organobor (Br) - на 34 суток позднее по отношению контролю. При этом формирование массовой технической спелости головок (у 100\%) происходило намного дружнее, и фаза сокращалась: при применении препарата Агростимул - на 13 суток, Лигногумат - на уровне контроля, а препаратов Экосил и Organobor (Br) - наоборот, увеличивалась на 1 и 5 суток по отношению К контролю.

Дружность созревания головок определяется длительностью периодов от начала хозяйственной годности (у 10\% растений) до массовой спелости (у 100\% растений). Необходимо отметить, что период начала хозяйственной годности (10\% головок) и полной спелости (100\%) центральных головок проходил дружнее. Продолжительность периода хозяйственной годности головок у Hybrid Cape Queen (от 10\% до 100\% растений) была более укорочена. Период массовой уборки урожая с применением препаратов составил 12, 10, 13, 8 суток, соответственно. При этом в контрольном варианте период уборки был более растянут - 36 суток (табл. 1).

Таблица 1. Анализ периода созревания головок сортов брокколи, 2015-2016 годы

$\mathrm{n} / \mathrm{n}$

Название препарата

\section{Дата созревания центральных головок}

$10 \%$

$100 \%$

$10 \%$

$100 \%$

сутки

Cорт Burpess green bud

\begin{tabular}{|c|c|c|c|c|c|c|}
\hline 1 & Агростимул & 28.08 & 21.09 & 01.09 & 24.09 & 23 \\
\hline 2 & Лигногумат & 09.09 & 24.09 & 11.09 & 26.09 & 15 \\
\hline 3 & Экосил & 25.09 & 18.10 & 27.09 & 21.10 & 25 \\
\hline 4 & Organobor (Br) & 22.09 & 13.10 & 23.09 & 15.10 & 23 \\
\hline 5 & Контроль (вода) & 05.09 & 19.10 & 08.09 & 21.10 & 44 \\
\hline
\end{tabular}

Hybrid Cape Queen

\begin{tabular}{|c|c|c|c|c|c|c|}
\hline 1 & Агростимул & 26.09 & 07.10 & 28.09 & 10.10 & 12 \\
\hline 2 & Лигногумат & 09.10 & 20.10 & 12.10 & 22.10 & 10 \\
\hline 3 & Экосил & 09.10 & 21.10 & 10.10 & 23.10 & 13 \\
\hline 4 & Organobor (Br) & 17.10 & 25.10 & 19.10 & 27.10 & 8 \\
\hline 5 & Контроль (вода) & 13.09 & 20.10 & 16.09 & 22.10 & 36 \\
\hline
\end{tabular}


Таблица 2. Морфобиологические изменения сортов брокколи, 2015-2016 годы

\begin{tabular}{|c|c|c|c|c|c|c|c|}
\hline \multirow[t]{2}{*}{$n / n$} & \multirow[t]{2}{*}{$\begin{array}{l}\text { Название } \\
\text { препарата }\end{array}$} & \multicolumn{2}{|c|}{$\begin{array}{c}\text { Размеры } \\
\text { товарной головки, см }\end{array}$} & \multirow[t]{2}{*}{$\begin{array}{l}\text { Форма } \\
\text { головки }\end{array}$} & \multicolumn{2}{|c|}{$\begin{array}{l}\text { Розетка, } \\
\text { см }\end{array}$} & \\
\hline & & $\mathrm{h}$ & $d$ & & $\mathrm{~h}$ & $d$ & \\
\hline \multicolumn{8}{|c|}{ Сорт Burpess green bud } \\
\hline 1 & Агростимул & 13,5 & 13,9 & округлая & 80,0 & 72,4 & 3,9 \\
\hline 2 & Лигногумат & 13,7 & 14,0 & округлая & 76,8 & 73,4 & 4,0 \\
\hline 3 & Экосил & 13,8 & 13,5 & округлая & 75,7 & 74,3 & 3,8 \\
\hline 4 & Organobor (Br) & 14,5 & 15,0 & округло-вытянутые & 77,5 & 71,6 & 3,9 \\
\hline 5 & Контроль (вода) & 14,3 & 13,0 & округлая & 69,2 & 63,3 & 3,0 \\
\hline & $\mathrm{HCP}$ & 0,9 & 1,2 & & 2,7 & 2,8 & \\
\hline \multicolumn{8}{|c|}{ Hybrid Cape Queen } \\
\hline 1 & Агростимул & 15,3 & 14,5 & округло-вытянутые & 74,2 & 90,4 & 4,0 \\
\hline 2 & Лигногумат & 13,4 & 15,4 & округло-плоская & 70,5 & 78,4 & 4,0 \\
\hline 3 & Экосил & 12,2 & 13,4 & округлая & 75,5 & 83,3 & 4,0 \\
\hline 4 & Organobor (Br) & 10,5 & 14,5 & округло-плоская & 70,6 & 83,5 & 3,8 \\
\hline \multirow[t]{2}{*}{5} & Контроль (вода) & 12,4 & 14,0 & округло-плоская & 72,3 & 81,2 & 3,0 \\
\hline & $\mathrm{HCP}$ & 1,8 & 1,2 & & 2,0 & 2,8 & \\
\hline
\end{tabular}

Таким образом, сорт Burpes sgreen bud (США) выделился по скороспелости, а Hybrid Cape Queen (Япония) - дружностью созревания товарных головок.

Генеративные побеги (головка) появляются при формировании достаточно крупной розетки, количество листьев которой и величина после этого продолжают возрастать (аналогично капусте цветной). Нами были отмечены морфологические различия у растений сортов, а также наблюдали их некоторые изменения в зависимости от вариантов препаратов (табл.2).

У сорта Burpess green bud высота головки по вариантам опыта составляла 13,5-14,5 см (контроль - 14,3 см); диаметр головки 13,5-15,0 см (контроль -
13,0 см). Форма головки округлая, индекс формы головок 0,97-1,02 (контроль 1,1). Высота растений составляла 75,7-80,0 см (контроль - 69,2 см); диаметр растений 71,6-74,3 см (контроль - 63,3см). Качество головок у сорта было высоким 3,8-4,0 балла (контроль - 3,0).

У гибрида Hybrid Cape Queen высота головок составляла 10,5-15,3 см (конт-

Таблица 3. Характеристика сортов брокколи по урожайности, 2015-2016 годы

\begin{tabular}{|c|c|c|c|c|c|c|}
\hline \multirow{2}{*}{$n / n$} & \multirow{2}{*}{$\begin{array}{l}\text { Название } \\
\text { препарата }\end{array}$} & \multicolumn{4}{|c|}{ Урожайность, кг/делянки } & \multirow{2}{*}{$\begin{array}{c}\text { Общая } \\
\text { урожайность } \\
\text { І-ІІІІ порядка, кг }\end{array}$} \\
\hline & & центральные головки & I порядок & II порядок & III порядок & \\
\hline \multicolumn{7}{|c|}{ Сорт Burpess green bud } \\
\hline 1 & Агростимул & 7,02 & 0,68 & 1,78 & 1,95 & 4,41 \\
\hline 2 & Лигногумат & 5,61 & 0,93 & 0,31 & 0,37 & 1,61 \\
\hline 3 & Экосил & 5,97 & 0,53 & 0,56 & 0,25 & 1,34 \\
\hline 4 & Organobor (Br) & 6,63 & 0,37 & 0,69 & 0,53 & 1,59 \\
\hline 5 & Контроль (вода) & 5,34 & 0,21 & 0,41 & 0,37 & 0,99 \\
\hline & $\mathrm{HCP}$ & 1,1 & 0,7 & 1,0 & 1,1 & 1,6 \\
\hline \multicolumn{7}{|c|}{ Hybrid Cape Queen } \\
\hline 1 & Агростимул & 6,33 & 0,47 & 0,43 & 0,15 & 1,05 \\
\hline 2 & Лигногумат & 5,94 & 0,31 & 0,32 & 0,38 & 1,01 \\
\hline 3 & Экосил & 5,58 & 0,47 & 0,51 & 0,47 & 1,45 \\
\hline 4 & Organobor (Br) & 5,97 & 0,34 & 0,16 & 0,51 & 1,01 \\
\hline 5 & Контроль (вода) & 4,71 & 0,32 & 0,19 & 0,29 & 0,80 \\
\hline & $\mathrm{HCP}$ & 1,1 & 0,4 & 0,5 & 0,5 & 0,7 \\
\hline
\end{tabular}


роль - 12,4 см); диаметр - 13,4-15,4 см (контроль - 14,0см). Форма головки округлая, округло-плоская и округловытянутая. Индекс формы головок 0,721,06 (контроль 0,88). Высота растений составляла 70,5-75,5 см (контроль - 72,3 см); диаметр растения - 78,4-90,4 см (контроль - 81,2 см). Качество головок высокое - 3,8-4,0 балла (контроль - 3,0) (табл. 2).

Нужно отметить, качество головки во многом зависит в южных широтах от температурного фактора в период роста и развития: чем она выше, тем головка бывает более рыхлой.

Продуктивность и качество сорта тесно
Выявлено, что у сорта Burpess green bud более результативным был вариант с применением препарата Агростимул: урожайность центральных головок составила 7,02 кг (в контроле - 5,34), боковых (I-ІІІ порядка) - 4,41 кг (в контроле 0,99), общая урожайность с делянки - 11,43 кг (контроль - 6,33) (табл. 3). Урожайность в остальных трех вариантов также была выше контроля: вариант с Лигногуматом 5,61 кг и 1,61 кг; Экосил - 5,97 кг и 1,34 кг; Organobor $(\mathrm{Br})-6,63$ кг и 1,59 кг, соответственно.

У гибрида Hybrid Cape Queen также наблюдали самую высокую урожайность в варианте с применением препарата щими препаратами не отмечено формирования головок I-III порядка, а масса центральных головок составила 0,4-0,71 кг (в контрольном варианте - 1,43 кг). В 2016 году все опытные варианты превышали контроль. В наших исследованиях отмечено, что препарат Агростимул более эффективен и повышает массу головки на $181 \%$ у сорта Burpess green bud, у Hybrid Cape Queen - на 134 \% (табл. 4). Macca дополнительных головок I-ІІІ порядка превышает контрольный вариант на $445 \%$ и 131\%, соответственно.

Ростостимулирующие препараты Лигногумат и Organobor (Br) также оказывают влияние на массу центральных голо-

Таблица 4. Эффективность использования ростостимулирующих препаратов, 2015-2016 годы

\begin{tabular}{|c|c|c|c|c|c|}
\hline \multirow[b]{2}{*}{$n / n$} & \multirow{2}{*}{$\begin{array}{l}\text { Название } \\
\text { препарата }\end{array}$} & \multicolumn{4}{|c|}{ Продуктивность растения брокколи, г } \\
\hline & & $\begin{array}{c}\text { масса } \\
\text { центральной головки }\end{array}$ & $\begin{array}{c}\%, \\
\text { к контролю }\end{array}$ & $\begin{array}{c}\text { масса } \\
\text { пазушных головок }\end{array}$ & $\begin{array}{c}\%, \text { к контролю } \\
\text { пазушных головок }\end{array}$ \\
\hline \multicolumn{6}{|c|}{ Burpess green bud } \\
\hline 1 & Агростимул & 234 & 181 & 147 & 445 \\
\hline 2 & Лигногумат & 187 & 114 & 54 & 163 \\
\hline 3 & Экосил & 199 & 116 & 45 & 135 \\
\hline 4 & Organobor (Br) & 221 & 130 & 53 & 161 \\
\hline 5 & Контроль (вода) & 178 & & 33 & \\
\hline \multicolumn{6}{|c|}{ Hybrid Cape Queen } \\
\hline 1 & Агростимул & 211 & 134 & 35 & 131 \\
\hline 2 & Лигногумат & 198 & 126 & 34 & 126 \\
\hline 3 & Экосил & 186 & 127 & 48 & 181 \\
\hline 4 & Organobor (Br) & 199 & 127 & 34 & 126 \\
\hline 5 & Контроль (вода) & 157 & & 27 & \\
\hline
\end{tabular}

взаимосвязаны с облиственностью растений у брокколи. Используемыми органами в пищу у брокколи являются центральная головка и боковые побеги в генеративном или вегетативном состоянии.

В результате проведенных работ установлено, что обработка рассады и вегетирующих растений капусты брокколи ростостимулирующими препаратами повышает адаптивность растений, стимулирует их рост, развитие, формирование головок, увеличивает урожайность, продлевает период формирования головок ІIII порядка (пазушные головки) (табл. 3) и улучшает их качество (табл. 2).

В исследованиях выявлено, что сортовая реакция по динамике нарастания ассимиляционного аппарата при обработке препаратами не одинакова, отмечена избирательная особенность.
Агростимул: масса центральных головок составила 6,33 кг, дополнительных головок - 1,05 кг, общая урожайность делянкообразца - 7,38 кг. Урожайность в контрольном варианте составила: центральных головок - 4,71 кг, дополнительных 0,80 кг, общая урожайность - 5,51 кГ (табл. 3). Незначительное увеличение по продуктивности показали варианты с применением Лигногумата - 5,94 кг и - 1,01 кг; Экосила - 5,58 кг и 1,45 кг; Organobor (Br) - 5,97 кг и 1,01 кг, соответственно, что также выше по сравнению с контролем.

Известный факт, что прищипка или уборка центральных головок растений у брокколи - необходимый агроприем для усиления роста и развития растений и увеличения количества боковых побегов.

В 2015 году у гибрида Hybrid Cape Queen при обработке ростостимулирую- вок: у сорта Burpess green bud она составила 187 г и 221г, соответственно; у гибрида Hybrid Cape Queen - 198 г и 199 г. В этих вариантах масса головок второго порядка: у сорта повысилась на 163 и $161 \%$, соответственно, у гибрида - на $126 \%$.

Препарат Экосил повышает масса головки стабильно у обоих сортообразцов: у сорта Burpess green bud она составила 199 г, у Hybrid Cape Queen- 186, дополнительная масса головок второго порядка превысила контроль на 135 и 181\%, соответственно.

\section{Заключение}

Таким образом, по нашим наблюдениям, период наступления хозяйственной годности сортов брокколи (сентябрьноябрь) значительно варьировал в зависи- 
мости от температурного режима года, и, в частности, от времени наступления оптимальной для образования головок температуры.

Использование ростостимулирующих препаратов в открытом грунте южных регионов страны имеет перспективы в целях повышения адаптивности и урожайности растений при круглогодичном выращивании овощей и неоднократном использовании единицы пахотной земли. Важно
изучИть ИХ ЭффеКТИВНОсть И ВыЯВИТь ОПтИмальные препараты, более подходящие для региона. В наших исследованиях большую эффективность проявил препарат Агростимул, повышая урожайность центральных головок у сорта Burpess green bud на 181\%, у Hybrid Cape Queen - на 134\%, а дополнительных (I-III порядка) - на 445 \% и 131\%, соответственно.

Обработка рассады и вегетирующих растений после высадки и в начале обра- зования головок ростостимулирующими препаратами является эффективным способом стимуляции роста и развития растений и ускорения формирования головок брокколи.

Автор приносит свою благодарность за консультацию и помощь в проведении данной работы Куркиеву У.К. и Мисриевой Б.У.

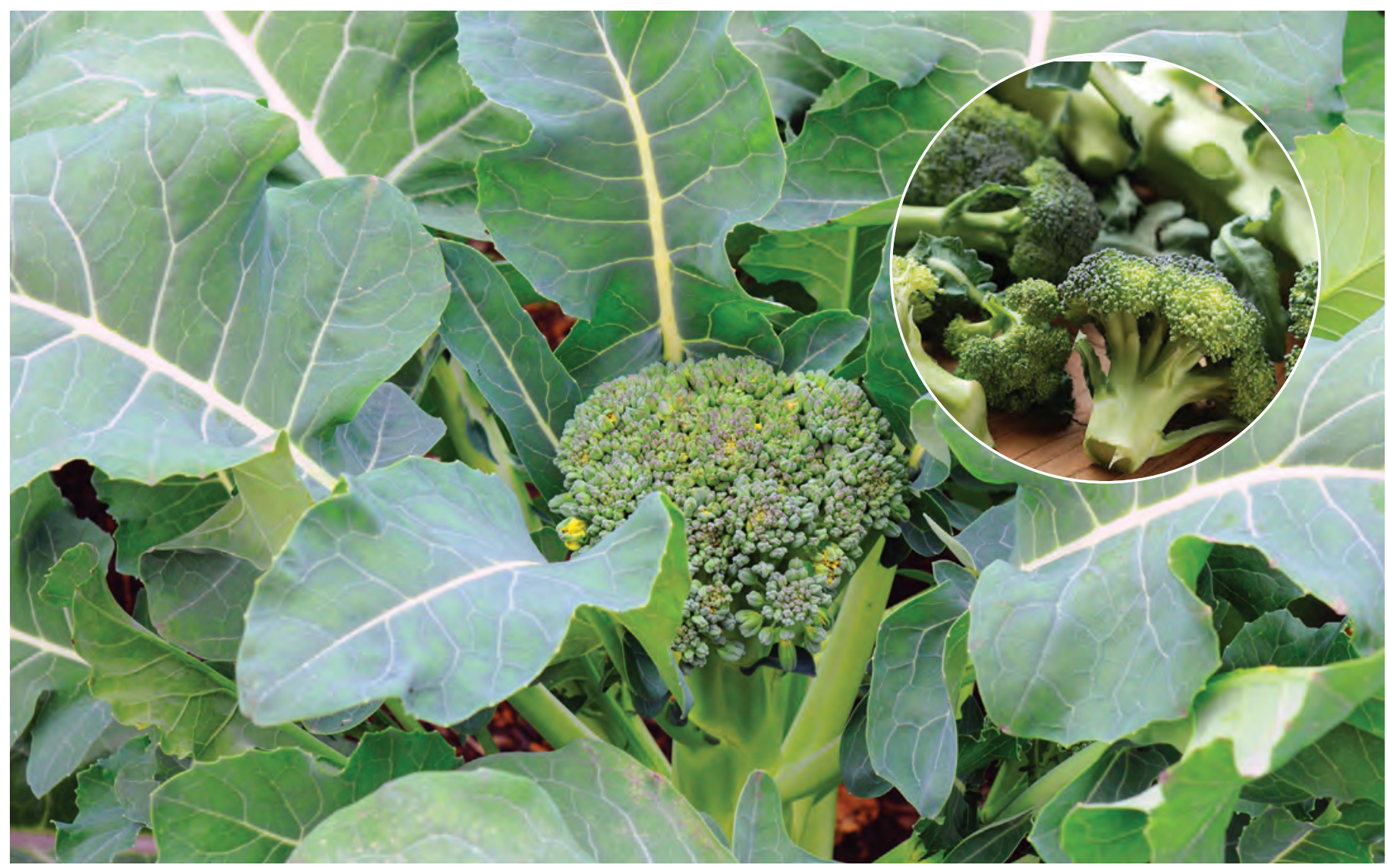

Литература

1. Лизгунова Т.В. Культурная фрлора «Капуста» Ленинград, «Колос» 1984. T. XI. - 328 c.

2. Пивоваров В.Ф. Селекция и семеноводства овощных культур. М. 2007. - (С.310). -808 C

7.Капуста брокколи / Приусадебное хозяйство. Выращивание капусты // Аст-Сталкер. 2006. (С. 45-50).- 94 с.

4.Лобыкина Е.Н., Колтун В.З., Хвостова О.И. Гликемический индекс продуктов и использование его в диетотерапии ожирения / Е.Н. Лобыкина, В.З. Колтун, О.И. Хвостова // Вопросы питания. Том.76. - № 1. - 2007. -C.14-21.

5. Мухортов С.Я., Кузнецов А.О. Применение биологически активных веществ в агроценозах капусты цветной и брокколи в ЦЧР / С.Я. Мухортов, А.О. Кузнецов // Сборник научных трудов по овощеводству и бахчеводству. ВНИИО Москва. 2009. - С.322-324.

6. Матевосян Г.Л., Шишов А.Д. Монография. Регуляция роста и продуктивности основных овощных культур и картосреля // Великий Новгород. 2007. -С. 55-73.

7. Овощеводство. Под ред. Тараканова Г.И., Мухина В.Д. М. Колос. 2003. - С. 286-305.

8. Будыкин Н.П., Алексеева Т.Ф., Хилков Н.И. Эффрективность применения новых экологически чистых регуляторов роста в растениеводстве европейского Севера / Н.П. Будыкина., Т.Ф. Алексеева, Н.И. Хилков // Северная Европа в XXI веке: природа, культура, экономика. Материалы международной конференции, посвященной 60-летию Кар. НЦ. РАН. "Биологические науки» Петрозаводск. 2006. - C.58-60

9. Шишов А.Д., Садовников А.С., Матов А.В. Действие иммуноцитосита, новосила и хитосроса на болезнеустойчивость цветной капусты / А.Д. Шишов, А.С. Садовников, А.В. Матов // Вестник защиты растений. - 2002. - № 1. - С.56-57.

10. Матевосян Г.Л., Шишов А.Д., Садовников А.С. Влияние новых регуляторов роста и индукторов устойчивости на физиолого-биохимические показатели цветной капусты / Г.Л. Матевосян, А.Д.Шишов, А.С. Садовников // Известия Санкт-Петербургского государственного аграрного университета. - Санкт-Петербург. 2008. - № 10. - С.41-45.

11. Лигногумат. Общая инсоормация, методика и результаты применения / Рекомендации для агрономов. Санкт-Петербург. 2012. $50 \mathrm{c}$.

12. Доспехов Б.А. Методика полевого опыта (с основами статистической обработки результатов исследований) - М.: Агропромиздат, 1985. - 416 c.

13. Рациональное использования земельных ресурсов / Л.А. Велибекова, Л.С. Даибова, Г.Р. Сердерова // Проблемы развития АПК региона. - 2014. - Т.20. - № 4 (20). -С.108-112.

14. Агроконсалт. Ежеквартальный журнал. 2013. - № 1 (11). -С.2324.

15. Arora S.K., Vashistha R.N., Partap P.S. Effect of cytozyme and miracula jn yield of cauliflower, cabbage and Knol - Knol // J. Hort. Sci. 1989. - V.18. - № 1-2. - P. 94-98. 